Available online on 15.09 .2020 at http://jddtonline.info
Open Access to Pharmaceutical and Medical Research
unrestricted non-commercial use, provided the original work is properly cited

Open $\odot$ Access

Research Article

\title{
Identification and Characterization of Staphylococcus aureus 16S rRNA gene isolated from different Food Specimens from South Indian Region
}

\author{
Mondeddu Kiran Kumar¹, Charu Tyagi², Arjun Sahu1, Nalini Desai3 , Jayanand Manjhi1, Kakarla Chandra Mohan5, \\ Yugandhar P. Reddy ${ }^{3}$, Santosh Kumar Tiwari ${ }^{4}$, Lomas Kumar Tomar ${ }^{*}$, Varun Kumar Sharma1,4* \\ ${ }^{1}$ Department of Biotechnology \& Microbiology, School of Sciences, Noida International University-NIU, Gautam Budh Nagar-201308, Uttar \\ Pradesh, India \\ 2 Department of Biotechnology, VSPG (PG) College, CCS University, Meer ut-250004, Uttar Pradesh, India \\ ${ }^{3}$ Department of Zoology, TheAdoni Arts and Science College, Adoni, Kurnool, Andhra Pradesh, India \\ ${ }^{4}$ Centre for Liver Research and Diagnostics, Deccan College of Medical Sciences, Kanchanbagh, Hyderabad 500 058, Telangana, India \\ ${ }^{5}$ Department of Zoology, KVR Government Degree College for Women, Kurnool, Andhra Pradesh, India
}

\begin{abstract}
Staphylococcus aureus (S. aureus) associated food-borne diseases have global impact on human health. Genome wide analyses have shown that $S$. aureus contains specific endotoxin expressing gene and produce toxic proteins which is responsible for food contamination. Appropriate detection of pathogens is one of the major tool to avoid infection rate and reduce the health and socio-economic burden to human being. In addition, inappropriate handing the specimens, misdiagnosis and limited standard medical support could directly influence the infection rate.

The objective of this study was to identify $S$. aureus from different food specimens from Hyderabad, India. A total of 70 random bacterial nutrient agar medium pure plates were made based on different morphological appearance of bacterial colonies. Preliminary identification of $S$. aureus based on standardized morphological method showed specific golden yellow colonies. Biochemical assay also verified bacterial specimens. Furthermore, molecular characterization was performed on the basis of polymerase chain reaction (PCR) and sequencing of $16 \mathrm{~S}$ rRNA gene of $S$. aureus. Newly sequenced $16 \mathrm{~S}$ rRNA gene sequences showed $100 \%$ homology to $S$. aureus, analyzed using NCBI-BLAST tool.

The phylogenetic analysis and nucleotide base composition studies performed using 39 sequences of 16S rRNA gene from different isolates of Staphylococcus, including Staphylococcus aureus. For the purpose, 16S rRNA gene sequences were retrieved from the NCBI in FASTA format. The phylogenetic analysis was performed using Maximum Likelihood method and revealed the relationships and percent similarity of Staphylococcus aureus $16 \mathrm{~S}$ rRNA gene.
\end{abstract}

Keywords: Food-borne diseases; 16S rRNA gene; Maximum Likelihood; Phylogenetic analysis; Staphylococcus aureus.

Article Info: Received 10 July 2020; Review Completed 11 August 2020; Accepted 18 August 2020; Available online 15 September 2020

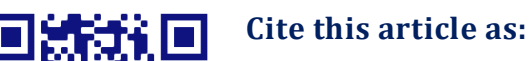

Kumar MK, Tyagi C, Sahu A, Desai N, Manjhi J, Mohan KC, Reddy YP, Tiwari SK, Tomar LK, Sharma VK, Identification and Characterization of Staphylococcus aureus 16S rRNA gene isolated from different Food Specimens from South Indian Region, Journal of Drug Delivery and Therapeutics. 2020; 10(5):24-32 http://dx.doi.org/10.22270/jddt.v10i5.4340

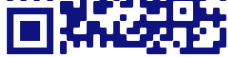

*Address for Correspondence:

Dr. Varun Kumar Sharma, Head, Department of Biotechnology and Microbiology, School of Sciences, Noida International University-NIU, Sector17 A, Yamuna Expressway Gautam Budh Nagar -201308, Uttar Pradesh, India.

\section{INTRODUCTION}

Food-borne associated disease is a one of the major health problem around the world, including food-borne intoxications and food-borne infections ${ }^{1,2}$. As per reference to Foodborne Disease Burden Epidemiology Reference Group (FERG) Report published in 2010, it has been estimated 3-5 billion people affected to food-borne associated disease and nearly 1.5 million deaths annually assumed worldwide ${ }^{3}$. Food-borne associated diseases mainly caused by a wide variety of pathogen, including bacterial species such as Salmonella spp., Vibrio spp., Clostrodium spp., Campylobacter spp., Salmonella spp., Campylobacter spp., and Staphylococcus spp 4 .

Staphylococcus aureus is a one of the major causative agent of food-borne associated disease and most prompt sporadic food-borne diseases are linked to Staphylococcus aureus, in the different region of the world 4,5 . Staphylococcus aureus mainly found in food stuff which grows and produce endotoxins result contaminating the food material6-8. The ubiquitous Staphylococcus species are observed to found a wide variety of food materials, including vegetarian and nonvegetarian items, range from raw, cooked and ready-to-eat 
foods stuff, which increase the risk for all consumers and can affect financial burden to the society ${ }^{9,10}$. The higher survival probability range of Staphylococcus aureus have been observed that it can survive in low to high temperature range and can grow in different $\mathrm{pH}$ range from acidic to alkaline medium $^{11}$. A limited laboratory practices are available to evaluate and the confirmation of Staphylococcus aureus for the commercial diagnostic purpose. Additionally, misdiagnosis, lack of standard medical attention and mishandling the specimens are also increase the risk of misinterpretation Staphylococcus aureus prevalence 12-14.

The genome of Staphylococcus aureus is approximately 2.3 Million base pair (bp) which mainly consists housekeeping genes, set of virulence genes and other genes required for growth and survival ${ }^{15}, 16$. Staphylococcus aureus has been isolated about seven decade ago from human specimen, and from the first isolation to till date, it is a one of the most extensively studied bacterial strain by various research groups from different countries around the world $15-17$. It has been observed that pathogenesis of Staphylococcus aureus control mainly by group of thirty genes, including basic survival gene and virulent genes $15,16,18$.

The bacterial genome wide sequencing analysis approaches have been developed tool that effectively efficiently help to recognize the specific bacterial strains, including $16 \mathrm{~S}$ rRNA gene sequencing19-20. Genome sequence analysis also provides a platform to compare genome diversity as well as help to understand the evolutionary association in intra- and inter-species populations. Interestingly, for the molecular detection of Staphylococcus aureus can be easily performed by amplifying the $16 \mathrm{~S}$ sRNA and other endotoxin virulent gene sequence ${ }^{19-22}$. In the current study, primarily, we focused to screen and identify Staphylococcus aureus strain from different food materials, including processed/canned food, home sterilized food and unsterilized/raw food using microbial and biochemical assay. Further, we aimed to validate and characterize 16S rRNA gene amplification and DNA sequencing method. We have also performed the multiple sequence alignment and phylogenetic tree to identify the genetic variation and evolutionary relationship between different isolate of Staphylococcus aureus.

\section{MATERIALS AND METHODS}

\section{Collection food specimen}

The study was carried out over a 6-months period from the region of Hyderabad, Telangana State of India. Food material samples were collected from the local food stores, road-side hawkers and home using sterile sample collection method, from the selected regions. Based on the availability food materials, specimens were classified in three independent categories, such as: (1) Processed and canned food (2) Home sterilized food and (3) Raw and unsterilized food

\section{Preparation of the bacterial culture}

Collected specimens were subjected for microbial isolation using basic plating technique on nutrient agar medium. The samples were separately macerated/mashed and added to $10 \mathrm{ml}$ of sterile distilled water and homogenously mixed. $0.1 \mathrm{ml}$ of this sample solution was used for spreading onto the nutrient agar plates under laminar airflow conditions. The plates were incubated in an inverted position for overnight at $37^{\circ} \mathrm{C}$.

\section{Screening and selection of bacterial specimen}

From the 18 master plates obtained a total of 70 random bacterial nutrient agar medium pure plates were made based on different morphological appearance of their colonies. The names of collected food samples and the number of pure plates obtained from them are shown in the table 1 .

Table 1: Detail of collected Food samples and quantity utilized for the current study.

\begin{tabular}{|c|c|c|c|c|c|c|}
\hline \multirow{2}{*}{ S. No. } & \multicolumn{2}{|c|}{ Processed and canned food } & \multicolumn{2}{|c|}{ Home sterilized food } & \multicolumn{2}{|c|}{ Raw and unsterilized food } \\
\hline & Food material & (n) & Food material & (n) & Food material & (n) \\
\hline 1 & Milk & 4 & Idli & 4 & Dosa & 4 \\
\hline 2 & Canned sweet & 4 & Steamed Rice & 5 & Sweet & 6 \\
\hline 3 & Instant curry (Veg) & 5 & $\begin{array}{c}\text { Homemade Curry } \\
\text { (Veg) }\end{array}$ & 3 & Noodles & 6 \\
\hline 4 & $\begin{array}{l}\text { Instant curry (Non- } \\
\text { Veg) }\end{array}$ & 6 & $\begin{array}{l}\text { Homemade Curry } \\
\text { (Non-Veg) }\end{array}$ & 3 & Bhajji & 4 \\
\hline 5 & Canned juice & 5 & $\begin{array}{l}\text { Coconut Paste } \\
\text { (Chutney) }\end{array}$ & 5 & Pani Poori & 6 \\
\hline 6 & Instant Idly batter & 5 & Fresh juice & 2 & Road-side fruit juice & 4 \\
\hline
\end{tabular}

$n=$ number of samples

\section{Preliminary identification of Staphylococcus species.}

All bacterial specimen culture were primarily subjected for gram staining along with the morphological characterization of bacterial populations, mainly Staphylococcus species. We have adopted standardized morphological method to identify the Staphylococcus colonies with golden yellow color and watery consistency 23,24 . All identified colonies were further subjected for depth morphological observation using grams staining method.

\section{Biochemical identification method.}

On the basis of preliminary morphological observation, selected colonies of Staphylococcus species were subjected for biochemical assay. We have performed basic biochemical assay such Catalase, Coagulase, Methyl Red Voges Proskauer, Mannitol and DNase Tests. 


\section{Molecular characterization of Staphylococcus species}

Morphological and Biochemical assay based positive samples of Staphylococcus species were further processed for molecular characterization method using PCR based assay. Details are given below:

\section{Genomic DNA Extraction from the selected bacterial cultures}

DNA extraction from bacterial colonies were performed using Sodium dodecyl sulfate (SDS)-based method ${ }^{25}$, 26. The bacterial cell suspension was treated with a lysis buffer containing SDS, Trisaminomethane Hydrochloric acid (Tris $\mathrm{HCl}$ ) and Ethylene-diaminetetra-acetic acid (EDTA). The Cell debris and other impurities were removed in several steps sequentially with simultaneous centrifugation. The Genomic DNA were precipitated using chilled ethyl alcohol. The precipitated DNA was collected as a pellet by centrifugation. The pellet was dissolved in TE buffer and stored at $4^{\circ} \mathrm{C}$ until next use.

After extraction of the genomic DNA from bacterial colonies, we aimed to verify the Staphylococcus aureus by $16 \mathrm{~S}$ rRNA sequence using PCR method, which is highly sensitive, compared to the most common microbial culture and staining techniques. For the purpose, we aimed to design a specific set of primers to amplify the $16 \mathrm{~S}$ rRNA sequence.

\section{Staphylococcus aureus 16S rRNA sequence retrieval and primer designing}

The Staphylococcus aureus strain ATCC 1260016 S ribosomal RNA, complete sequence (NR_118997.2) was retrieved from the National Center for Biotechnology Information (NCBI; http://www.ncbi.nlm.nih.gov) databases in FASTA format. Primer designing marker was designed using Primer 3 (V.0.4.0) online tool (http://bioinfo.ut.ee/primer30.4.0/primer3/).

\section{Amplification of 16S rRNA gene using PCR}

For the PCR reaction, total reaction volume was $50 \mu \mathrm{l}$, containing $5 \mu \mathrm{l}$ of DNA template, $1 \mathrm{U}$ Ampli Taq DNA polymerase, $10 \mathrm{pmol}$ of each primer (forward primer and reverse primer, purchased from Sigma-Aldrich, Hyderabad) $200 \mu \mathrm{mol}$ of each deoxyribonucleoside triphosphate per liter, $1.5 \mathrm{mmol}$ of $\mathrm{MgCl}_{2}$ per liter, $10 \mathrm{mmol}$ of Tris- $\mathrm{HCl}(\mathrm{pH}$ 8.8) per liter, $50 \mathrm{mmol}$ of $\mathrm{KCl}$ per liter, and $0.1 \%$ Triton $\mathrm{X}$ 100.

\section{Sequencing analysis of 16s rRNA gene}

The PCR product was purified the PCR product using QIAquick gel extraction kit (Qiagen, Germany). $15 \mu \mathrm{l}$ of the purified product was sequenced by use of the ABI Prism DNA sequencing kit, Big Dye Terminator Cycle Sequencing (version 3.0), and ABI Prism 310 genetic analyzer (Applied Biosystems, USA). Comparison of the sequence with those in a reference database was performed by using an identification program based on selection of the longest recursive matches for optimal alignment of the compared sequences. The reference database sequences retrieved and combined from NCBI GenBank. The final sequence comparisons to the best matches were done manually.

\section{Local sequence alignment}

Basic local Alignment Search Tool (BLAST) was performed for the different isolates of Staphylococcus aureus 16S ribosomal RNA gene sequence retrieved from NCBI to identify the homology or similarity its relatives in different isolated of Staphylococcus aureus using the online NCBIBLAST (https://blast.ncbi.nlm.nih.gov/Blast.cgi). This software takes the data in FASTA format and produces the BLAST table.

\section{Phylogenetic analysis}

Phylogenetic analysis of Staphylococcus aureus 16S ribosomal RNA gene sequence through Maximum likelihood methods were carried out using MEGA7 software 27. Phylogenetic trees were constructed by the software showing the ancestral relationship among the sequences. The Maximum Likelihood phylogenic tree give different clusters showing their evolution relationship with each other and tree reveals different clade showing their evolutionary relationship within different isolates of Staphylococcus aureus. The sequences which lie in the same cluster are closely related.

\section{RESULTS AND DISCUSSION}

\section{Sequence retrieval}

Staphylococcus aureus strain ATCC 12600 16S ribosomal RNA, complete sequence was retrieved from the NCBI in FASTA format. The sequence of the gene (NR_118997.2) is as the following:

$>$ NR_118997.2 Staphylococcus aureus strain ATCC 12600 $16 \mathrm{~S}$ ribosomal RNA, complete sequence.

\begin{abstract}
TTTATGGAGAGTTTGATCCTGGCTCAGGATGAACGCTGGCGGCGTGCCTAATACATGCAAGTCGAGCGAACGGACGAGAAGCTTGCTT CTCTGATGTTAGCGGCGGACGGGTGAGTAACACGTGGATAACCTACCTATAAGACTGGGATAACTTCGGGAAACCGGAGCTAATACCG GATAATATTTTGAACCGCATGGTTCAAAAGTGAAAGACGGTCTTGCTGTCACTTATAGATGGATCCGCGCTGCATTAGCTAGTTGGTA AGGTAACGGCTTACCAAGGCAACGATACGTAGCCGACCTGAGAGGGTGATCGGCCACACTGGAACTGAGACACGGTCCAGACTCCTAC GGGAGGCAGCAGTAGGGAATCTTCCGCAATGGGCGAAAGCCTGACGGAGCAACGCCGCGTGAGTGATGAAGGTCTTCGGATCGTCTCT GTTATTAGGGAAGAACATATGTGTAAGTAACTGTGCACATCTTGACGGTACCTAATCAGAAAGCCACGGCTAACTACGTGCCAGCAGC CGCGGTAATACGTAGGTGGCAAGCGTTATCCGGAATTATTGGGCGTAAAGCGCGCGTAGGCGGTTAAGTCTGATGTGAAAGCCCACGG CTCAACCGTGGAGGGTCATTGGAAACTGGAAAACTTGAGTGCAGAAGAGGAAAGTGGAATTCCATGTGTAGCGGTGAAATGCGCAGA GATATGGAGGAACACCAGTGGCGAAGGCGACTTTCTGGTCTGTAACTGACGCTGATGTGCGAAAGCGTGGGGATCAAACAGGATTAGA TACCCTGGTAGTCCACGCCGTAAACGATGAGTGCTAAGTGTTAGGGGGTTTCCGCCCCTTAGTGCTGCAGCTAACGCATTAAGCACTCC GCCTGGGGAGTACGACCGCAAGGTTGAAACTCAAAGGAATTGACGGGGACCCGCACAAGCGGTGGAGCATGTGGTTTAATTCGAAGCA ACGCGAAGAACCTTACCAAATCTTGACATCCTTTGACAACTCTAGAGATAGAGCCTTCCCCTTCGGGGGACAAAGTGACAGGTGGTGC ATGGTTGTCGTCAGCTCGTGTCGTGAGATGTTGGGTTAAGTCCCGCAACGAGCGCAACCCTTAAGCTTAGTTGCCATCATTAAGTTGG GCACTCTAAGTTGACTGCCGGTGACAAACCGGAGGAAGGTGGGGATGACGTCAAATCATCATGCCCCTTATGATTTGGGCTACACACG TGCTACAATGGACAATACAAAGGGCAGCGAAACCGCGAGGTCAAGCAAATCCCATAAAGTTGTTCTCAGTTCGGATTGTAGTCTGCAA CTCGACTACATGAAGCTGGAATCGCTAGTAATCGTAGATCAGCATGCT ACGGTGAATACGTTCCCGGGTATTGTACACACCGCCCGTC ACACCACGAGAGTTTGTAACACCCGAAGCCGGTGGAGTAACCTTTTAGGAGCTAGCCGTCGAAGGTGGGACAAATGATTGGGGTGAAG TCGTAACAAGGTAGCCGTATCGGAAGGTGCGGCTGGATCACCTCCTTT
\end{abstract}




\section{Specific set of primers of Staphylococcus aureus $16 S$ rRNA DNA sequence}

Specific primer of Staphylococcus aureus 16S rRNA sequence was designed using Primer 3 (V.0.4.0) online tool, as depicted in Figure 1. We obtained a set of primer for $16 \mathrm{~S}$ rRNA sequence of covering 570 nucleotide sequence length. The length of forward primer/sense primer is 127 nucleotide (highlighted with red color) and reverse primer/antisense primer length is 705 nucleotide (highlighted with blue color). We observed primers are specific by using NCBI, primer blast and no primer-primer dimer. Primers were observed with no helping structure. We also check self-complementary alignment of a specific primer using Oligo Calc (Oligonucleotide properties calculator). Details of the primers sequences as well as the PCR programs and protocol are provided in Table 1.

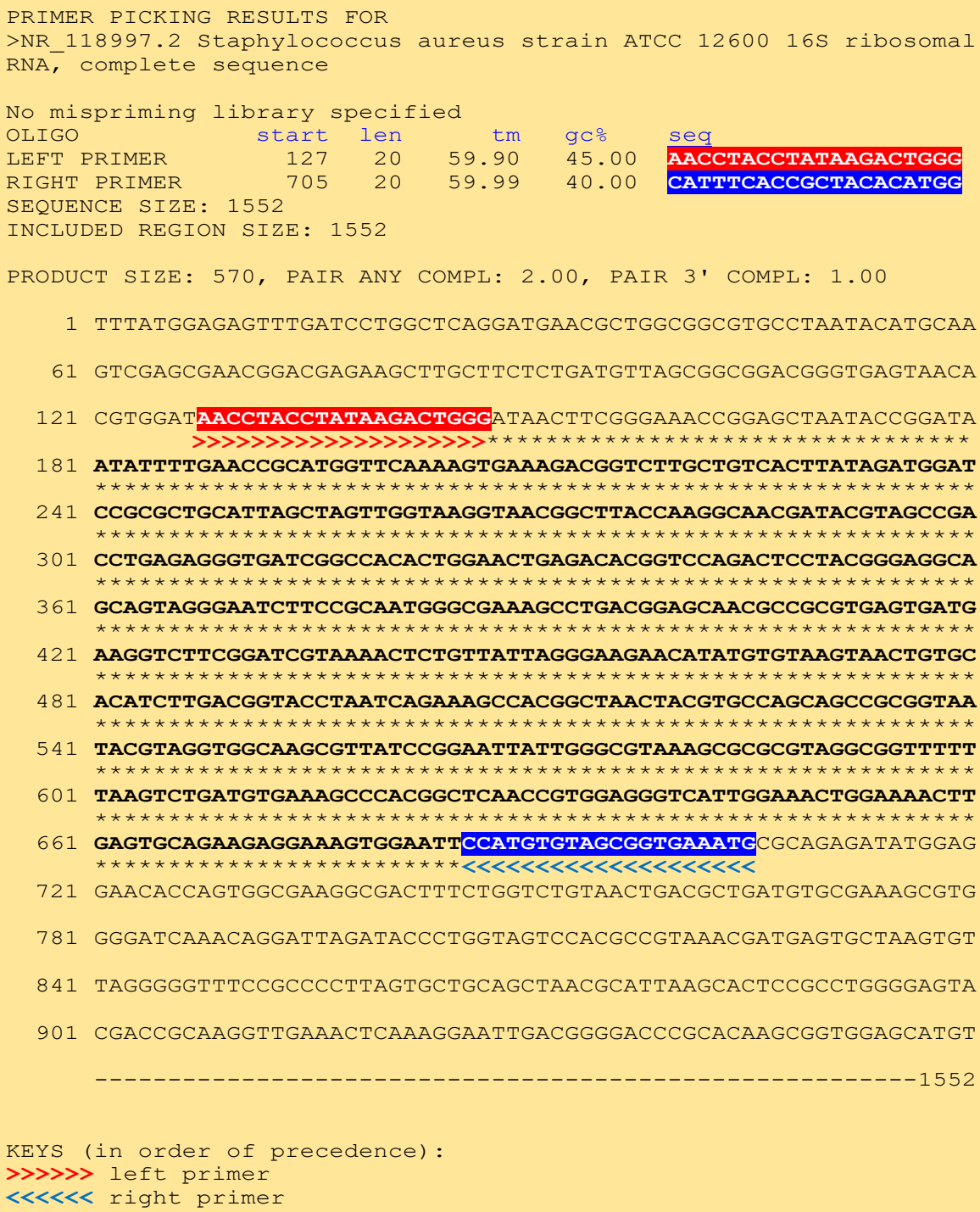

Figure 1: Staphylococcus aureus 16S rRNA gene Primer3 Output

Table 1: Detail of primers sequences used to amplify Staphylococcus aureus 16S rRNA gene using PCR.

\begin{tabular}{ccccc}
\hline \multirow{2}{*}{ Gene } & Primer type & Sequences & Primer & \multicolumn{2}{c}{$\begin{array}{c}\text { PCR Product } \\
\text { size }\end{array}$} \\
\hline \multirow{2}{*}{$\begin{array}{c}\text { 16S rRNA } \\
\text { PCR Primer }\end{array}$} & Forward primer & AACCTACCTATAAGACTGGG & $20 \mathrm{nt}$ & \multirow{2}{*}{$570 \mathrm{bp}$} \\
\cline { 2 - 4 } & Reverse primer & CATTTCACCGCTACACATGG & $20 \mathrm{nt}$ & \\
\hline
\end{tabular}




\section{Amplification of Staphylococcus aureus 16S rRNA gene using PCR}

Prepared PCR reaction mixtures were prepared as mentioned in material and method secession. Amplification of 16S rRNA gene was performed in a PCR Thermo Cyclers
(M) Research PTC 200) for 30 cycles by using the following parameters: denaturation at $95^{\circ} \mathrm{C}$ for 60 second, annealing at $54^{\circ} \mathrm{C}$ for 45 second, and extension at $72^{\circ} \mathrm{C}$ for $2 \mathrm{~min}$. The cycles were preceded by a denaturation step at $95^{\circ} \mathrm{C}$ for 5 min, followed by an extension step at $72^{\circ} \mathrm{C}$ for 4 min (Figure 2).

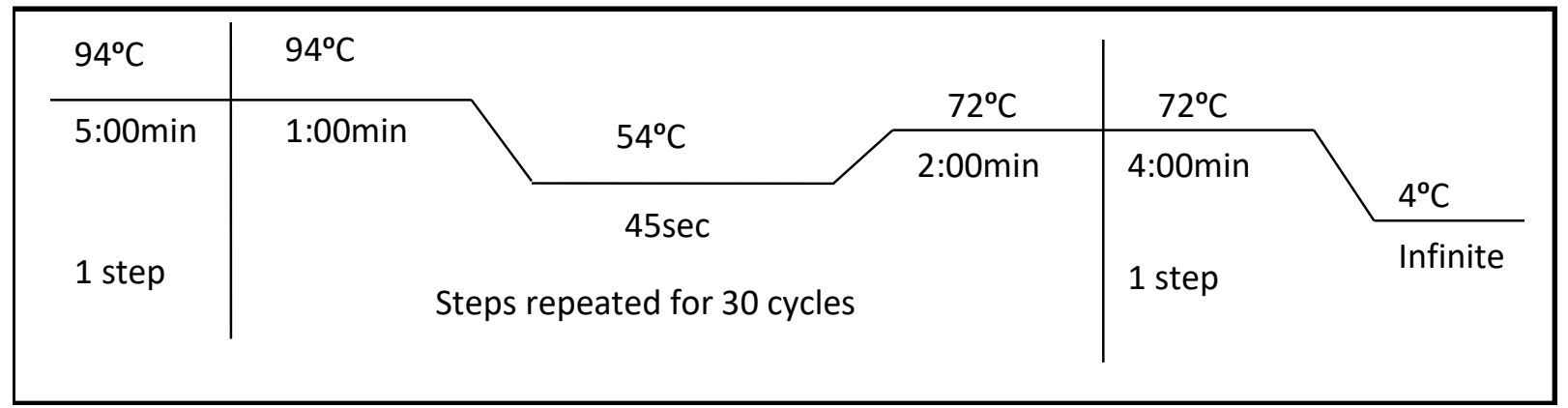

Figure 2: Adopted PCR condition to amplify the $16 \mathrm{~S}$ rRNA gene sequence.

\section{Visualization of PCR products through agarose gel electrophoresis}

After amplification by PCR, the 570 bp of PCR products of Staphylococcus aureus $16 \mathrm{~S}$ rRNA gene obtained were run on an agarose gel $1 \%$, at $100-120 \mathrm{~V}$. The gel was stained with ethidium bromide. The PCR products were then visualized under UV light in Tran illuminator (Safe Imager 2.0 BlueLight Transilluminator, ThermoFisher, Scientific, MA, USA).

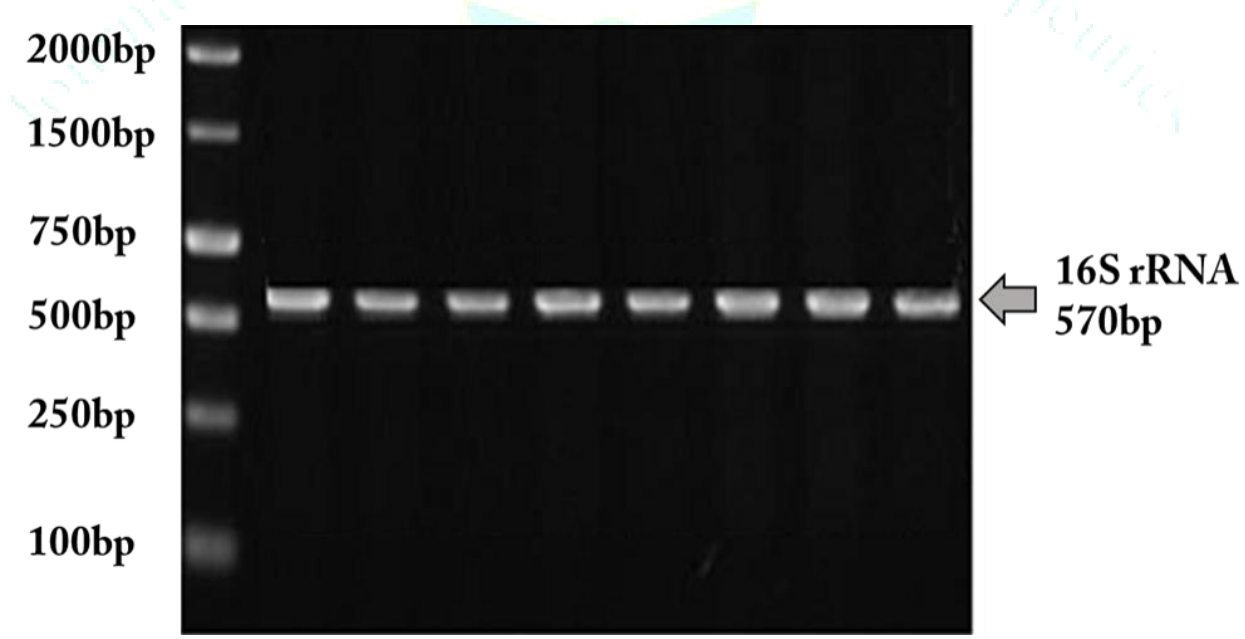

Figure 3: Agarose gel electrophoresis (1\%) represent amplification of 16S rRNA gene using PCR

\section{Local sequence alignment}

As mentioned in material and method session, we have sequenced 3 isolate of Staphylococcus aureus 16S rRNA and different isolates of Staphylococcus aureus 16S rRNA gene sequences were retrieved from the NCBI (https://www.ncbi.nlm.nih.gov/nuccore) in FASTA format, and performed local sequence alignment using online NCBI BLAST tool (https://blast.ncbi.nlm.nih.gov/Blast.cgi). After performing BLAST, the NCBI BLAST tool produced BLAST table (list of the aligned sequence) showing the description of the gene, accession numbers, percent similarity, e-value, etc (Table 2). 
Table 2: BLAST table of 16s RNA of Staphylococcus aureus

\begin{tabular}{|c|c|c|c|c|c|}
\hline $\begin{array}{c}\text { S. } \\
\text { No }\end{array}$ & Description & $\begin{array}{l}\text { Max } \\
\text { Score }\end{array}$ & $\begin{array}{l}\text { Total } \\
\text { Score }\end{array}$ & $\begin{array}{l}\% \\
\text { Identity }\end{array}$ & $\begin{array}{l}\text { Ref No./ } \\
\text { Accession }\end{array}$ \\
\hline 1. & 16S ribosomal RNA New Sequence 1 & 1068 & 1068 & 100 & New Seq 1 \\
\hline 2. & 16S ribosomal RNA New Sequence 2 & 1068 & 1068 & 100 & New Seq 2 \\
\hline 3. & $16 \mathrm{~S}$ ribosomal RNA New Sequence 3 & 1068 & 1068 & 100 & New Seq 3 \\
\hline 4. & Staphylococcus aureus strain sam2 16S rRNA gene, & 1068 & 1068 & 100 & MN540925.1 \\
\hline 5. & Staphylococcus aureus strain OS 16S rRNA gene, & 1068 & 1068 & 100 & MN508958.1 \\
\hline 6. & Staphylococcus aureus strain S1 16S rRNA gene, & 1068 & 1068 & 100 & MK881023.1 \\
\hline 7. & Staphylococcus aureus strain RB3 16S rRNA gene, & 1068 & 1068 & 100 & MK271755.1 \\
\hline 8. & Staphylococcus aureus strain ATCC 12600 16S rRNA, & 1068 & 1068 & 100 & NR_118997.2 \\
\hline 9. & Staphylococcus aureus strain FDS17 16S rRNA gene, & 1068 & 1068 & 100 & KM555283.1 \\
\hline 10. & Uncultured bacterium clone ncd154d09c1 16S rRNA gene, & 1068 & 1068 & 100 & HM260412.1 \\
\hline 11. & Staphylococcus aureus strain S11 16S rRNA gene, & 1068 & 1068 & 100 & FJ434470.1 \\
\hline 12. & S.aureus gene for $16 \mathrm{~S}$ rRNA & 1068 & 1068 & 100 & X68417.1 \\
\hline 13. & Uncultured bacterium clone nck261c06c1 16S rRNA gene, & 1062 & 1062 & 99.83 & KF099868.1 \\
\hline 14. & Uncultured bacterium clone nck159c11c1 16S rRNA gene, & 1062 & 1062 & 99.83 & KF092179.1 \\
\hline 15. & Uncultured bacterium clone nck138b11c1 16S rRNA gene, & 1062 & 1062 & 99.83 & KF090696.1 \\
\hline 16. & Uncultured bacterium clone nck121d02c2 16S rRNA gene, & 1062 & 1062 & 99.83 & KF089615.1 \\
\hline 17. & Uncultured bacterium clone ncd2387a04c1 16S rRNA gene & 1062 & 1062 & 99.83 & JF208017.1 \\
\hline 18. & Uncultured bacterium clone ncd2370e04c2 16S rRNA gene & 1062 & 1062 & 99.83 & JF207012.1 \\
\hline 19. & Uncultured bacterium clone ncd2357c11c1 16S rRNA gene & 1062 & 1062 & 99.83 & JF199790.1 \\
\hline 20. & Uncultured bacterium clone ncd2304c08c1 16S rRNA gene & 1062 & 1062 & 99.83 & JF197863.1 \\
\hline 21. & Uncultured bacterium clone ncd1985a06c1 16S rRNA gene & 1062 & 1062 & 99.83 & JF172707.1 \\
\hline 22. & Uncultured bacterium clone ncd1925e04c1 16S rRNA gene & 1062 & 1062 & 99.83 & JF165386.1 \\
\hline 23. & Uncultured bacterium clone ncd1368h07c1 16S rRNA gene & 1062 & 1062 & 99.83 & JF119960.1 \\
\hline 24. & Uncultured bacterium clone ncd1367a09c1 16S rRNA gene & 1062 & 1062 & 99.83 & JF119857.1 \\
\hline 25. & Uncultured Staphylococcus sp. clone VA21_59 16S rRNA & 1062 & 1062 & 99.83 & HM077151.1 \\
\hline 26. & Uncultured bacterium clone ncd943g01c1 16S rRNA gene, & 1062 & 1062 & 99.83 & HM330051.1 \\
\hline 27. & Uncultured bacterium clone ncd886e03c1 16S rRNA gene, & 1062 & 1062 & 99.83 & HМ307769.1 \\
\hline 28. & Uncultured bacterium clone ncd858b10c1 16S rRNA gene, & 1062 & 1062 & 99.83 & HM297895.1 \\
\hline 29. & Uncultured bacterium clone ncd702c03c1 16S rRNA gene, & 1062 & 1062 & 99.83 & HM291954.1 \\
\hline 30. & Uncultured bacterium clone ncd672d02c1 16S rRNA gene, & 1062 & 1062 & 99.83 & HM289952.1 \\
\hline 31. & Uncultured bacterium clone ncd739g04c1 16S rRNA gene, & 1062 & 1062 & 99.83 & HM289008.1 \\
\hline 32. & Uncultured bacterium clone ncd610b11c1 16S rRNA gene, & 1062 & 1062 & 99.83 & HM285212.1 \\
\hline 33. & Uncultured bacterium clone ncd597e08c1 16S rRNA gene, & 1062 & 1062 & 99.83 & HM284435.1 \\
\hline 34. & Uncultured bacterium clone ncd586e07c1 16S rRNA gene, & 1062 & 1062 & 99.83 & HM280583.1 \\
\hline 35. & Uncultured bacterium clone ncd585f03c1 16S rRNA gene, & 1062 & 1062 & 99.83 & HM280506.1 \\
\hline 36. & Uncultured bacterium clone ncd578c03c1 16S rRNA gene, & 1062 & 1062 & 99.83 & HM280017.1 \\
\hline 37. & Uncultured bacterium clone ncd567b11c1 16S rRNA gene, & 1062 & 1062 & 99.83 & HM279200.1 \\
\hline 38. & Uncultured bacterium clone ncd148f09c1 16S rRNA gene, & 1062 & 1062 & 99.83 & HM260038.1 \\
\hline 39. & Uncultured bacterium clone ncd32e11c1 16S rRNA gene, & 1062 & 1062 & 99.83 & HM247340.1 \\
\hline 40. & Staphylococcus aureus strain SAW1, complete genome & 1057 & 6268 & 99.65 & СР045468.1 \\
\hline 41. & Staphylococcus aureus strain UP_338 chromosome, genome & 1057 & 5287 & 99.65 & СР047851.1 \\
\hline 42. & Staphylococcus aureus strain UP_1442, genome & 1057 & 5287 & 99.65 & СР047802.1 \\
\hline 43. & Staphylococcus aureus strain UP_1106, genome & 1057 & 5287 & 99.65 & СР047863.1 \\
\hline 44. & Staphylococcus aureus strain UP_1322, genome & 1057 & 6344 & 99.65 & СР047861.1 \\
\hline 45. & Staphylococcus aureus strain UP_1525, genome & 1057 & 5287 & 99.65 & СР047854.1 \\
\hline 46. & Staphylococcus aureus strain UP_322, genome & 1057 & 6344 & 99.65 & СР047799.1 \\
\hline 47. & Staphylococcus aureus strain UP_1097, genome & 1057 & 6344 & 99.65 & СР047803.1 \\
\hline 48. & Staphylococcus aureus strain UP_1405, genome & 1057 & 5287 & 99.65 & СР047859.1 \\
\hline 49. & Staphylococcus aureus strain UP_296, genome & 1057 & 6344 & 99.65 & СР047800.1 \\
\hline 50. & Staphylococcus aureus strain UP_844, genome & 1057 & 6338 & 99.65 & СР047865.1 \\
\hline
\end{tabular}

It is clear from the BLAST results that newly sequenced Staphylococcus aureus 16S rRNA gene have shown 100\% identity with different Staphylococcus aureus 16S rRNA genes submitted at NCBI GenBank such as, Staphylococcus ISSN: 2250-1177 [29] aureus strain sam2 16S ribosomal RNA gene (MN540925.1), Staphylococcus aureus strain OS 16S ribosomal RNA gene (MN508958.1), Staphylococcus aureus strain S1 16S ribosomal RNA gene (MK881023.1), Staphylococcus aureus 
strain RB3 16S ribosomal RNA gene (MK271755.1), Staphylococcus aureus strain ATCC 12600 16S ribosomal RNA (NR_118997.2), Staphylococcus aureus strain FDS17 16S ribosomal RNA gene (KM555283.1), Uncultured bacterium clone ncd154d09c1 16S ribosomal RNA gene (HM260412.1), Staphylococcus aureus strain S11 16S ribosomal RNA gene (FJ434470.1), S.aureus gene for $16 \mathrm{~S}$ rRNA (X68417.1). However, other uncultured 16S rRNA gene sequence with accession number KF099868.1, KF092179.1, KF090696.1, KF089615.1, JF208017.1, JF207012.1, JF199790.1, JF197863.1, JF172707.1, JF165386.1, JF119960.1, JF119857.1, HM077151.1, HM330051.1, HM307769.1, HM297895.1, HM291954.1, HM289952.1, HM289008.1, HM285212.1, HM284435.1, HM280583.1, HM280506.1, HM280017.1, HM279200.1, HM260038.1, HM247340.1, CP045468.1, CP047851.1, CP047802.1, CP047863.1, CP047861.1, CP047854.1, CP047799.1, CP047803.1, СР047859.1, CP047800.1 and CP047865.1 shown 99.65 to 99.83 homology with newly sequenced 16S rRNA of Staphylococcus aureus. (Table 5).

\section{Phylogenetic analysis}

The phylogenetic analysis included the newly sequenced Staphylococcus aureus 16S rRNA and retrieved 16S rRNA sequences of different isolates from NCBI database. Staphylococcus aureus 16S rRNA gene sequences alignments were generated using MEGA7 (ver 7.0.26) tool. Individual dendrograms were generated using different methods, namely the maximum likelihood methods. Phylogenetic groups and subgroups were defined by the length and branching order of the concatenated gene tree. The resulting groups were supported by high bootstrap values.

In Phylogenetic analysis, alignment of nucleotide sequences is a major consideration, particularly in studies of genes from divergent taxa. It seems obvious to state that the phylogenetic analysis of sequences begins with the appropriate alignment of the data themselves, yet alignment remains one of the most difficult and poorly understood facets of molecular data analysis. Alignments of the genomic sequences are required to analyze the phylogenetic tree. Phylogenetic analysis often includes the search for evidence of directional selection in molecular evolution ${ }^{28,29}$. Evolution of the 16S RNA was studied in different isolates of Staphylococcus aureus and adaptive changes were in the sequences. The phylogenetic analysis of the Staphylococcus aureus 16S rRNA gene dataset resulted in a tree consistent with modern systematic understanding of the relatedness among different species of Staphylococcus genus, mainly based on DNA sequences homology (Figure 4).

In order to determine the genus of the bacterial isolates collected from the different food specimens, we have amplified and sequenced the 16S rRNA gene of bacterial group. The obtained sequences were BLAST against NCBI's 16S rRNA GenBank ${ }^{31}$. The evolutionary history was inferred by using the Maximum Likelihood method based on the Tamura-Nei model ${ }^{30}$. The phylogenetic analysis performed using 39 sequences of $16 \mathrm{~S}$ rRNA gene from newly and retrieved 16S rRNA sequences, including Staphylococcus aureus. The consensus tree inferred from 10 most parsimonious trees is shown. Branches corresponding to partitions reproduced in less than $50 \%$ trees are collapsed. The consistency index is 1.000000 (1.000000), the retention index is 1.000000 (1.000000), and the composite index is $1.000000(1.000000)$ for all sites and parsimonyinformative sites (in parentheses). The MP tree was obtained using the Subtree-Pruning-Regrafting (SPR) algorithm ${ }^{30}$ with search level 0 in which the initial trees were obtained by the random addition of sequences (10 replicates). The tree is drawn to scale with branch lengths calculated using the average pathway method and are in the units of the number of changes over the whole sequence. The analysis involved 39 nucleotide sequences. Codon positions included were 1 st+2nd+3rd+Noncoding. All positions containing gaps and missing data were eliminated. There were a total of 578 positions in the final dataset. Evolutionary analyses were conducted in MEGA727.

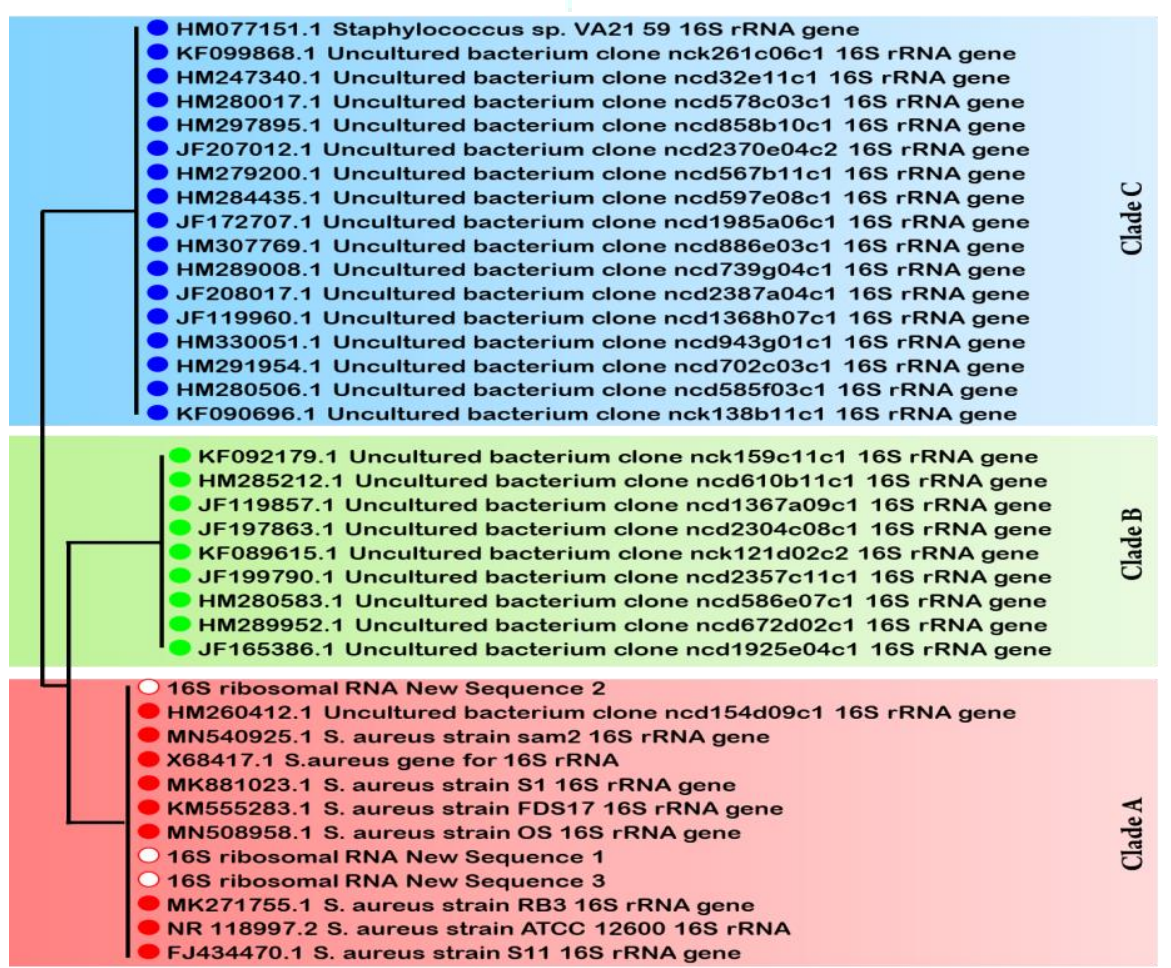

Figure 4. Molecular Phylogenetic analysis of 16S rRNA gene using Maximum Likelihood method. The evolutionary history was inferred using the Maximum Parsimony method ${ }^{30}$ and evolutionary analyses were conducted in MEGA727. 
The phylogenetic trees were constructed using Maximum likelihood method for the sequence of newly isolated bacteria from the food specimens. Maximum likelihood method is most suitable model to understand the evolutionary history of an organism. The bootstrap consensus trees inferred from 1000 replicates were taken to represent the evolutionary history of the taxa analyzed. The Maximum likelihood trees were obtained using the Nearest Neighbor-Interchange heuristic algorithm. All positions containing gaps and missing data were eliminated from the dataset (Complete Deletion option). Phylogenetic analyses were conducted in MEGA7 and obtained three major cluster (depicted in Figure 4), classified as Clade A (Red color), Clade B (Green Color) and Clade C (Blue Color). As depicted in figure 4, newly sequenced $16 \mathrm{~S}$ rRNA gene sequences were grouped with other isolates of Staphylococcus aureus in Clade A, with $100 \%$ homology obtained similar as in local alignment analysis. Clade B and Clade C shown 99\% homology with Clade A. however, both clades include different isolates of uncultured Staphylococcus species. The observations based on phylogenetic analysis of 16s RNA gene of Staphylococcus aureus using Maximum Likehood method revealed the relationships and percent similarity of 16s RNA gene within different bacterial isolates, including Staphylococcus species, Observations based on molecular techniques verified the major presence of Staphylococcus aureus in collected food specimens.

\section{CONCLUSION:}

Phylogenetic analysis of the Staphylococcus species, including new isolates from food specimens revealed that they are the same strain and are affiliated to Staphylococcus aureus. In recent years, Next Generation of Sequencing technologies boosted the genome databases and a remarkable increase in the number of sequenced genomes, drafts or complete, are available, but the correct assignation of the sequenced strains to the corresponding species with the accepted taxonomic tools is important before comparative analyses with other genomes can be performed. The need for the whole genome sequences of all the type strains, which are the only species references that are publicly available in culture collections, is evident. In the present study, we have identified and characterized Staphylococcus aureus from the clinical specimens, using molecular biology techniques. New 16sRNA sequences of Staphylococcus aureus isolated were aligned with Staphylococcus species and constructed phylogeny tree to determine the molecular evolution and population structure of Staphylococcus species using bioinformatics tools. The phylogenetic affiliations of the different species of the genus Staphylococcus aureus were shown by the Maximum likelihood based phylogenetic analyses using the 16S rRNA sequences. Our study demonstrated that positive selection of 16s RNA gene during the divergence of different isolate of Staphylococcus species during evolution. These evolutionary acquirements have made necessary changes in the genetic control of ontogeny, and this, in turn, might have caused adaptive changes in the 16s RNA gene.

\section{ACKNOWLEDGEMENTS}

This study is supported by Noida International UniversityNIU, Gautam Budh Nagar-201308, Uttar Pradesh, India. We acknowledge our thanks to the NIU Management team Dr. D. K. Singh (Chairman), Dr. V. Singh (Chancellor), Noida International University, for their support and allowing us to work at NIU.

\section{Conflicts of Interest Statement}

The authors declare no conflict of interests.

\section{REFERENCES}

1. Balaban N, Rasooly A, "Staphylococcal enterotoxins," International Journal of Food Microbiology. 2000; 61(1):1-10.

2. Loir YL, Baron F, Gautier M, "Staphylococcus aureus and food poisoning," Genetics and Molecular Research. 2003; 2 (1):6376.

3. Havelaar AH, Kirk MD, Torgerson PR, Gibb HJ, Hald T, Lake RJ, Praet N, Bellinger DC, de Silva NR, Gargouri N, Speybroeck N, Cawthorne A, Mathers C, Stein C, Angulo FJ, Devleesschauwer B, World Health Organization Foodborne Disease Burden Epidemiology Reference Group. World Health Organization Global Estimates and Regional Comparisons of the Burden of Foodborne Disease in 2010. PLoS Med. 2015; 12(12):e1001923.

4. Scallan E, Hoekstra RM, Angulo FJ, Tauxe RV, Widdowson MA, Roy SL, Jones JL, Griffin PM, Foodborne illness acquired in the United States--major pathogens. Emerg Infect Dis. 2011; 17(1):7-15.

5. Bennett SD, Walsh KA, Gould LH, Foodborne disease outbreaks caused by Bacillus cereus, Clostridium perfringens, and Staphylococcus aureus--United States, 1998-2008. Clin Infect Dis. 2013; 57(3):425-33.

6. Hennekinne JA, De Buyser ML, Dragacci S, Staphylococcus aureus and its food poisoning toxins: characterization and outbreak investigation. FEMS Microbiol Rev. 2012; 36(4):81536.

7. Kadariya J, Smith TC, Thapaliya D, Staphylococcus aureus and staphylococcal food-borne disease: an ongoing challenge in public health. Biomed Res Int. 2014; 2014:827965.

8. Umeda K, Nakamura H, Yamamoto K, Nishina N, Yasufuku K, Hirai Y, Hirayama T, Goto K, Hase A, Ogasawara J, Molecular and epidemiological characterization of staphylococcal foodborne outbreak of Staphylococcus aureus harboring seg, sei, sem, sen, seo, and selu genes without production of classical enterotoxins. Int J Food Microbiol. 2017; 256:30-35.

9. Sofos JN, Challenges to meat safety in the 21st century, Meat Science. 2008; 78(2):3-13.

10. Syne SM, Ramsubhag A, Adesiyun AA, Microbiological hazard analysis of ready-to-eat meats processed at a food plant in Trinidad, West Indies. Infect Ecol Epidemiol. 2013; 19:3.

11. Chaibenjawong $P$, Foster SJ, Desiccation tolerance in Staphylococcus aureus. Arch Microbiol. 2011; 193(2):125-35.

12. Guerrant RL, Van Gilder T, Steiner TS, Thielman NM, Slutsker L, Tauxe RV, Hennessy T, Griffin PM, DuPont H, Sack RB, Tarr P, Neill M, Nachamkin I, Reller LB, Osterholm MT, Bennish ML, Pickering LK, Infectious Diseases Society of America. Practice guidelines for the management of infectious diarrhea. Clin Infect Dis. 2001; 32(3):331-51.

13. Scallan E, Jones TF, Cronquist A, Thomas S, Frenzen P, Hoefer D, Medus C, Angulo FJ, FoodNet Working Group. Factors associated with seeking medical care and submitting a stool sample in estimating the burden of foodborne illness. Foodborne Pathog Dis. 2006; 3(4):432-8.

14. Argudín MÁ, Mendoza MC, Rodicio MR, Food poisoning and Staphylococcus aureus enterotoxins. Toxins (Basel). 2010; 2(7):1751-73.

15. Cassat JE, Dunman PM, McAleese F, Murphy E, Projan SJ, Smeltzer MS, Comparative genomics of Staphylococcus aureus musculoskeletal isolates. J Bacteriol. 2005; 187(2):576-92.

16. Chua KY, Stinear TP, Howden BP, Functional genomics of Staphylococcus aureus. Brief Funct Genomics. 2013; 12(4):30515.

17. Adelson L, Sudden and unexpected deaths in infancy and childhood. Ann West Med Surg. 1952; 6(2):95-7.

18. Bae T, Banger AK, Wallace A, Glass EM, Aslund F, Schneewind O, Missiakas DM, Staphylococcus aureus virulence genes identified by bursa aurealis mutagenesis and nematode killing. Proc Natl Acad Sci U S A. 2004; 101(33):12312-7.

19. Janda JM, Abbott SL, $16 \mathrm{~S}$ rRNA gene sequencing for bacterial identification in the diagnostic laboratory: pluses, perils, and pitfalls. J Clin Microbiol. 2007; 45(9):2761-4.

20. Matsuda K, Tsuji H, Asahara T, Kado Y, Nomoto K, Sensitive quantitative detection of commensal bacteria by rRNA-targeted reverse transcription-PCR. Appl Environ Microbiol. 2007; 73(1):32-9.

21. Zemanick ET, Wagner BD, Sagel SD, Stevens MJ, Accurso FJ, Harris JK, Reliability of quantitative real-time PCR for bacterial 
detection in cystic fibrosis airway specimens. PLoS One. 2010; 30; 5(11):e15101.

22. Saruta K, Hoshina S, Machida K, Genetic identification of Staphylococcus aureus by polymerase chain reaction using single-base-pair mismatch in $16 \mathrm{~S}$ ribosomal RNA gene. Microbiol Immunol. 1995; 39(11):839-44.

23. Reimann HA, Micrococcus tetragenus Infection II. Description of Variant Forms, J Bacteriol. 1936; 31(4):385-405.

24. Shaw C, Stitt JM, Cowan ST, Staphylococci and their Classification. J. gen. MimoMol. 1951; 5:1010-1023.

25. Goldenberger D, Perschil I, Ritzler M, Altwegg M, A simple "universal" DNA extraction procedure using SDS and proteinase $\mathrm{K}$ is compatible with direct PCR amplification. PCR Methods Appl. 1995; 4(6):368-70.

26. Natarajan VP, Zhang $X$, Morono $Y$, Inagaki F, Wang F, A Modified SDS-Based DNA Extraction Method for High Quality
Environmental DNA from Seafloor Environments. Front Microbiol. 2016; 23(7):986.

27. Kumar S., Stecher G., and Tamura K, MEGA7: Molecular Evolutionary Genetics Analysis version 7.0 for bigger datasets.Molecular Biology and Evolution. 2016; 33:1870-1874.

28. Hofmann J, Renz M, Meyer S, von Haeseler A, Liebert UG, Phylogenetic analysis of rubella virus including new genotype I isolates. Virus Res. 2003; 96 (1-2):123-8.

29. Hsu HW, Su HY, Huang PH, Lee BL, Liu HJ, Sequence and phylogenetic analysis of P10- and P17-encoding genes of avian reovirus. Avian Dis. 2005; 49(1):36-42.

30. Tamura $K$, Nei M, Estimation of the number of nucleotide substitutions in the control region of mitochondrial DNA in humans and chimpanzees. Molecular Biology and Evolution. 1993; 10:512-526.

31. Altschul SF, Gish W, Miller W, Myers EW, Lipman DJ, Basic local alignment search tool. J Mol Biol. 1990; 215 (3):403-10. 